\title{
EL ENSAMBLAJE DE UNA ESCULTURA DEL SIGLO XVII
}

\author{
por Pedro Gonzalez Garcia
}

El objetivo que pretendemos conseguir con este compendio de noticias, es dar a conocer una serie de elementos poco frecuentes, y a simple vista no apreciados por la retina del historiador del arte.

En esta esfera de la expresión humana que denominamos creación artística, la actividad específica de la escultura es el proceso de representación de una idea en tres dimensiones. El objeto escultórico es por tanto sólido, tridimensional y ocupa un espacio. Pero siempre lo analizamos exteriormente, nunca valoramos cómo y de qué forma fue realizado, nunca evaluamos los pormenores interiores de lo que está compuesta la obra.

De igual forma que en el Renacimiento son sus planteamientos antropocéntricos, al hombre se le ubicaba según leyes ópticas y reglas científicas, algunos artistas e intelectuales empezaron a observar nuestro propio mecanismo interior, elementos fundamentales para saber como se rige y actua. En la actualidad conocer el interior de la obra escultórica es captar su sentido de la forma y de su proyección hacia el espectador que es elemento fundamental para quien está realizada.

La escultura al ocupar nuestro mismo espacio vital debemos valorarla en sus múltiples elementos constitutivos, tanto exteriores como interiores, estos últimos, menos conocidos y tratados por los historiadores del arte.

La reciente celebración del Tercer Centenario de la Muerte de Pedro de Mena, nos hace recordar la restauración de una Dolorosa del citado autor, del Museo de Bellas Artes de Sevilla, llevada a cabo por el restaurador D. José Rodríguez-Rivero Carreras, bajo la iniciativa del actual Conservador del mismo Dr. D. Enrique Pareja López, en su momento Director del complejo museográfico.

La obra de Pedro de Mena ha sido estudiada desde fines del siglo XIX por especialistas de escultura como: Valladar, F. de P.; Torres Acevedo, M.; Sentenach, N. y en el siglo XX por los especialistas: Orueta y Duarte, R.; Gómez-Moreno Martínez, M.; Gomez-Moreno, María Elena; Sánchez-Mesa 
Martín, D., y por último, Bernales Ballesteros, J. y Martín González, J.J. Pero ninguno trata de esta sobresaliente pieza escultórica del artista granadino del Museo de Bellas Artes de Sevilla, ni estilística, ni formalmente ${ }^{1}$.

Nuestro informe pretende completar esta laguna en cuanto a catalogación bibliográfica y publicar datos que proceden del taller de restauración tan importantes para ${ }^{\circ}$ comprender mejor el mundo o el contexto en el que fue realizada la escultura barroca, escenográfica y teatral.

La Dolorosa de Pedro de Mena (fig. 1) forma parte de la colección donada, al Museo de Bellas Artes de Sevilla, por D. Rafael González Abreu en 1928².

Estuvo localizada hasta la década de los sesenta, en la Sala que llevaba el nombre de su donante ${ }^{3}$; con posterioridad pasó a las salas correspondientes a la Iglesia del antiguo convento mercedario, sede del $\mathrm{Museo}^{4}$; de donde salió para ingresar en la Sala de Velázquez, de la que fue retirada para su completa restauración.

Como la mayoría de las obras que forman la Donación González Abreu, de la Virgen Dolorosa de Pedro de Mena, no se tienen noticias de propiedad anteriores a la compra e ingreso en la colección particular de la que procede, de donde directamente pasó a formar parte de las colecciones del museo sevillano. Estos inconvenientes hacen que la pieza sea difícil de catalogar, y emitir un juicio cierto sobre su lugar de origen; por tanto, nos limitaremos a estudiarla como obra escultórica de evidente calidad, comparable con las mejores tallas del maestro granadino.

El análisis formal de la obra en su faceta; iconográfica, descriptiva, estilística, cronológica y posteriormente estructural, derivada de la restauración, nos llevarán a conclusiones que mejorarán, sin duda, el conocimiento de la escultura de Pedro de Mena.

El origen del tema de la Dolorosa o Virgen de la Soledad, se identifica consustancialmente con el espíritu de patetismo flamenco de fines de la Edad Media, y es en los últimos años del siglo XV, cuando se crea el tipo iconográfico

1. Valladar, F. de P.: El San Francisco de Toledo. El escultor granadino Pedro de Mena.. «La Alhambra». Granada, 1898. Torres Acevedo, M.: Rev. "Asociación Artística y Arqueológica de Barcelona». Mayo-Junio. Barcelona, 1898. Sentenach, N.: Rev. «Archivos, Bibliotecas y Museos», n. ${ }^{\circ}$ 8-9, Madrid, 1899. Orueta y Duarte, R.: La vida y la obra de Pedro de Mena y Medrano. Ed. Centro de Estudios Históricos. Madrid, 1914. Gómez-Moreno Martínez, M. Pedro de Mena, Escultor. Homenaje en su Tercer Centenario. Málaga, 1928. Gómez-Moreno, María Elena: "Cuadernos de Arte». Vol. III, Granada, 1938. Sánchez-Mesa Martín, D.: Técnica de la Escultura Policromada Granadina. Granada, 1972. Bernales Balleresteros, J.: Rev. «Anuario de Estudios Americanos». T. XXXI, Sevilla, 1974. Martín González, J.J.: Escultura Barroca en España 1600-1700. Cátedra, Madrid, 1983. La última publicación que pone al día todos los estudios sobre el artista y la más completa, es la editada con motivo del III Centenario de la Muerte del mismo: Catálogo-Exposición: Pedro de Mena. Junta de Andalucía, Consejería de Cultura, Abril, Málaga, 1989.

2. Donación: González Abreu, 26 de Mayo de 1928.

3. La Dolorosa. Escultura en madera policromada. Pedro de Mena. Siglo XVII. 0,70 m. Hernández Díaz, José: Museo Provincial de Bellas Artes de Sevilla, Sevilla, 1967, p. 114. Cat. n. 539.

4. Museo de Bellas Artes de Sevilla: Pintura y Escultura, siglos XIV al XX. Dirección General de Bellas Artes. Ministerio de Educación y Ciencia. Madrid, 1971, p. 20. 
de esta; derivando a la Virgen de los Siete Dolores, representados por puñales, que se individualizará, posteriormente, avanzado el Renacimiento, hasta crearse el canónico prototipo de la Soledad o Dolorosa ${ }^{5}$.

Esta iconografía de la Virgen totalmente identificada y personalizada, adquiere en Granada y especialmente en su escuela de talla, unos rasgos propios, claramente identificables; que consisten en tratar el tema de medio busto. Sus comienzos se remontan al Bajo Renacimiento, al gusto por representar las imágenes de medio cuerpo, para colocar un sagrario o encuadrar una reliquia, de donde deriva el «busto sagrario» o «busto relicario», de sabor manierista, cuyo nacimiento procede de regiones italianas, de donde pasaron a las escuelas españolas, para afincarse definitivamente, y con gran raigambre en la granadina, en la que crea un tipo característico y personal, dentro de toda la geografía peninsular.

La Dolorosa de Pedro de Mena, del Museo de Bellas Artes de Sevilla, es partícipe de las características anteriormente expuestas (fig. 1). Es una talla de madera de más de medio busto, comparable a otras realizaciones autógrafas del maestro; su rostro es pequeño, de frente reducida, las cejas son rectas, los párpados grandes e inclinados hacia arriba, la nariz recta, los pómulos salientes, la mandíbula ancha con la boca entreabierta, el mentón fuerte, las orejas quedan descuidadas, pauta habitual en todas las tallas de su mano, y el esqueleto del rostro se acusa con vigor ${ }^{6}$; en general, refleja una dulzura subyugada al drama de su Hijo. Las esculturas de Pedro de Mena son la personalificación de almas solitarias, imágenes que emanan, de la madera en la que están hechas, el sentimiento y el lirismo que su autor puso en su gubia. Rasgos físicos faciales, similares a los de la Dolorosa del mismo artista, conservada en el convento avulense de Alba de Tormes ${ }^{7}$. El cuello alargado y de poca descripción anatómica, sirve de nexo de unión entre la cabeza y la túnica, de cuyo interior salen los brazos, rematados por las ampulosas bocamangas de la túnica, que se reducen hasta llegar a las manos, por los puños blancos de una supuesta camisa interior. Las manos unidas, no cruzadas, sino entrecruzadas ante el pecho, se dirigen hacia el frente, en actitud de oración, similares a las de la talla del mismo tema del autor, del Convento del Cister de Málaga ${ }^{8}$; y no hacia arriba, implorando, como las de la Dolorosa del canónigo malagueño Moreno Maldonado?.

El manto, de paños sueltos, libres y despegados de la talla general, presenta un grosor aproximado al de la tela real, y está realizado con una lámina del-

5. Reau, Louis: L'Iconographie de l'Art Chretiens. París, 1955-1959. T. II, pp. 104-105.

6. Para analizar los rasgos físicos de las Dolorosas del artista. Véase: Orueta y Duarte, Ricardo de: La vida y obra de Pedro de Mena y Medrano. Madrid, 1914, pp. 29-30.

7. La Dolorosa del Convento de Carmelitas de Alba de Tormes (Avila), recuerda la composición facial de esta, aunque sus manos están en distinta posición a la tratada, y su manto y túnica son de mayor movilidad. Véase: Ibidem, pp. 171-173. Fig. 59.

8. Véase, Ibidem, pp. 249-250. Fig. 132.

9. Véase, Ibidem, pp. 252. Fig. 137. 
gadísima de madera, visible por uno y otro lado. Esta forma de tratar la madera en finísimas superficies lisas y moldeables, fue una técnica muy habitual entre los escultores de la escuela castellana del siglo XVI, que la usaron, generalmente, en lugares determinados de las esculturas policromadas; modelado en madera que Mena aprendería de su maestro Cano, y este a su vez del castellano Gregorio Fernández.

Las esculturas de medio o más de medio busto, que son características personales del maestro, y con posterioridad de la escuela que creó, son tallas ejecutadas para sobremesa, para un altar o para no ser movidas de su hornacina; consecuencia lógica de su origen en la imagen de «busto sagrario o relicario» de donde derivan; tienen un sólo punto de vista, generalmente frontal, en donde el autor desarrolla toda su creatividad artística. Suelen ir sobre peanas rectangulares o de ángulos achatados, decoradas a base de molduras rectilineas.

Estas características coinciden en la Dolorosa del Museo, que puede fecharse entre los años de 1658 a 1670; años posteriores a la ejecución magistral del Coro de la Catedral malagueña, en la etapa considerada por Orueta y Duarte, como de transición entre el segundo y tercer período del artista granadino; momento en el que la producción de imágenes religiosas femeninas, en sus facciones, se generalizan con los rasgos siguientes: rostros geometricamente ovales, cuello cilíndrico y poco modelado, cejas rectas, los ojos se agrandan, la nariz se estrecha y la boca se entreabre y empequeñece ${ }^{10}$.

Las Dolorosas de Pedro de Mena, suelen tener su paralelo iconográfico, de medio busto o busto solamente, en los Ecce Homos, que responden a las mismas pautas compositivas y raices originarias del patetismo flamenco. Solían ser esculturas realizadas por encargo, en las que su propietario determinaba los rasgos físicos y estéticos de la talla encargada. Por tanto, no siguen el mismo modelo femenino, ya que el capricho o gusto personal era elemento decisorio en las obras del maestro granadino, como en la mayoría de los imagineros seiscentistas ${ }^{11}$.

Tras el análisis externo de la pieza, a continuación, nos remitimos a los datos aportados por el taller de restauración; noticias de interés, en cuanto a su composición estructural, amablemente ofrecidas por el restaurador del $\mathrm{Mu}$ seo, D. José Rodríguez-Rivero, quien realizó su paciente trabajo de consolidación.

En primer lugar, trataremos del estado en que entró la imagen en el taller, pormenorizando detalles de interés artístico, en donde se aprecia la técnica de modelado del artista, su forma de policromar y detalles varios, que ofrecen nuevas visiones plásticas de una escultura de Mena (fig. 2).

La ficha técnica de la talla, recibida del taller de restauración es la siguien-

10. Para estudiar los diferentes períodos estilísticos por los que pas 6 el maestro. Véase, Ibidem, pp. 36-40.

11. Véase: El artista, el cliente y la obra, en «Catálogo-Exposición: Pedro de Mena», Málaga, 1989. 
te: Virgen Dolorosa; figura de mas de medio busto; medidas: $0,66 \mathrm{~m}$. de alto x 0,61 m. de ancho máximo; escultura en madera policromada; ojos de cristal, tipo «cascarilla» pintados por detrás; boca entreabierta con dientes de marfil; manos unidas y entrecruzadas en el centro del pecho; cubierta externamente por un manto azul que envuelve toda la figura, dejando ver frontalmente el rostro, enmarcado por toca que imita grueso lienzo; la parte visible de la túnica son las mangas y un trozo junto al cuello.

La talla a su entrada en el taller, presentaba numerosos desperfectos (fig. 2); ya que la última restauración general sufrida por la misma, se fecha en 1969. En toda la superficie externa se aprecian gran número de uniones pegadas, con desviaciones de las piezas internas, e incluso algunas se hallaban sueltas, despefectos mucho más acusados en la zona dorsal de la escultura, correspondiente al manto. El azul del mismo, no era el original, sino de una restauración anterior; al apreciarse en algunos descascarillados de este, otro azul más claro y típico en las tallas de Mena.

La encarnadura del rostro se hallaba con varias manchas de suciedad y barnices de bordes gruesos chorreados; craquelado en su superficie total y más concretamente en la barbilla, de donde se habían desprendido diversas particulas de policromía. Faltan las lágrimas, habituales en estas Dolorosas, que tuvo posiblemente; por los restos que quedan, quizás, fuesen de un grueso barniz y no de cristal. En la unión de la cabeza con el cuello, se aprecian dos grietas producidas por los movimientos de la madera.

Las manos se encontraban bastante dañadas, por su posición saliente del general de la talla, a causa de golpes y desgastes por el roce de su encarnadura; todos los dedos tenían la policromía perdida, dejando vista la madera. Una particularidad, que creemos pauta general de la obra del maestro, es el estar realizadas las uñas de las manos, por trozos de láminas de asta de buey o semejante, de color blanco y posteriormente coloreadas; los engarces de cada una, así como los salientes eran los más dañados, hasta el punto de que la uña del meñique de la mano izquierda había desaparecido. Manos, que en su unión a los puños de la camisa interior, estaban burdamente fusionados y cubierto su nexo con pasta y trozos de papel grueso, imitando el original.

La toca sigue el esquema clásico de Mena, imitando un grueso tejido realizado en pasta de color blanco crudo y posteriormente rayada: en el lateral izquierdo de la toca y recorriendo la imagen en sentido vertical, aparecía una grieta bastante pronunciada, que se prolongaba desde el ángulo interior que forma la toca en el manto, pasando por el borde de la manga izquierda y terminaba en la base de la escultura. En su parte superior, por donde cubre la cabeza y en el lateral derecho, se aprecia un trozo de veintiseis centímetros de largo, por dos centímetros de ancho, añadido ultimamente, al igual que el arco superior saliente del manto.

La túnica roja, es poco visible, sólo muestra sus cualidades en las bocamangas y parte superior del pecho o cuello, propiamente dicho, de la misma. El 
color rojo de su policromía, es del tipo llamado «corlado», sobre oro mate, decorada su superficie por un círculo de contorno blanco, en cuyo centro remata con un trozo de nacar de unos cuatro milímetros, y en torno a este aparecen cuatro esquemáticas flores de tulipán, también de perfil blanco y punteadas en su interior, de tres centímetros y medio cada una (fig. 6).

La policromía y decoración de la túnica, en la parte superior y exterior de las mangas, habían perdido en gran parte el color rojo, no apreciándose los motivos citados, sólo vagamente, en lugares poco dañados por el desgaste de la policromía, como son las partes bajas de las bocamangas y rincones interiores reservados. Los bordes de las bocamangas, por ser unas partes más. en contacto con el ambiente externo, fueron rehechas completamente en su policromía.

Los puños de la camisa interior, están tallados y modelados a la forma anatómica de ambas zonas del extremo inferior del antebrazo; su parte más danada era la unión de estos con las manos; del original sólo se conservaban restos interiores de la misma.

El manto de color azul, presentaba posteriormente, tanto vertical como horizontalmente, las uniones de las diferentes piezas ensambladas, especialmente en la espalda, en donde se apreciaban las grietas, debidas a los estucos que, según el restaurador, al ser demasiado claros son procedentes de la restauración de 1969, ya que los antiguos suelen ser de tonalidades más crudas.

Sin duda, por las fuentes documentales llegadas a nosotros, podemos afirmar que las tallas salidas del taller de Pedro de Mena, eran policromadas, si no por él, bajo su directa supervisión ${ }^{12}$.

Esta policromía, siguiendo la moda de todo el siglo XVII, en Granada, en sumamente sencilla, con pocos bordados en las telas, y cuando estos aparecen, no son casi nunca estofados, sino motivos, como el descrito anteriormente de los tulipanes, realizados a punta de pincel. Posteriormente en sus últimos años, ya empezó a contagiarse de otros gustos, y solamente entonces estofaba y doraba con profusión; nota que acredita la datación de la Dolorosa del Museo de Bellas Artes de Sevilla, de fecha anterior a su etapa final. En cambio, donde Mena o sus pintores ponen todo su cuidado y primor, es en la encarnación, casi siempre mate y de una riqueza y suavidad de medias tintas, como no se encuentra en ningún otro imaginero de aquel momento, y que completa en muchos casos, y en todas hace resaltar, la finura y delicadeza del modelado o la fuerza y la complejidad de la expresión total.

La escultura, según su restaurador, presentaba un visible aumento de altura, en su parte inferior, de siete centímetros, de ejecución contemporánea o muy poco posterior a la talla original; posiblemente su ampliación sería motivada por su propietario, una vez acabada, le resultaría baja y pediría que le aumentaran en su superficie inferior, para ajustarla al lugar a ella destinado.

12. Véase, Ibidem, pp. 43-45. 
Fueron muchos y variados los problemas que presentaba la magnífica talla, por lo que se inició la lenta restauración, que se acometió eliminando, en primer lugar, el color azul oscuro del manto y los empastes que cubrían las grietas, que alteraban el modelado de la superficie original; mostrando al descubrirse, un tono azul más pálido, posiblemente mezcla de ultramar con blanco. Este tono azul, realizado con la técnica de la pintura al temple (fig. 2), originariamente fue practicado sobre una finísima capa de aparejo de yeso, muy tenue, sobre el que el pintor fue dando diversas capas de temple de color azul, realizadas en el mismo tono, pero según su grosor varían de intensidad; del azul, en las más finas, al agrisado en las más densas. Lo que presupone una segunda policromía de todo el manto, tras su aumento de altura, para igualar las superficies primitivas con la de la nueva talla, casi contemporánea.

El manto, como comentamos anteriormente, se encontraba con gruesas grietas, debidas al movimiento interior de las piezas ensambladas, por lo que se consideró oportuno abrir la talla por su parte posterior, para consolidarlas; esto, fue llevado a cabo por una de las grietas, que se derivaba de la prolongación de una de las juntas de las tablas ensambladas dorsalmente (fig. 4); para modelar la superficie del manto. La abertura efectuada dió a conocer la distribución estructural interna o ensamblaje de las piezas de madera, que sería la habitual en todas las Dolorosas de medio busto de Pedro de Mena y Medrano.

Si seguimos la fig. 3, donde la talla se dibuja en Vista Inferior en Planta, analizaremos las diversas piezas de madera que la forman ${ }^{13}$. El primer elemento ligneo que la constituye y el inicial, originariamente, su factura que Mena trataría, fue el nucleo central, señalado con la letra (A), o tarugo de madera de cedro, de posición vertical, al que le fueron adosadas diversas tablas de pino, también verticales, en posición paralela y vertical al frente de la imagen, como las señaladas con la letra (B), en sentido paralelo al frente; y las señaladas con la $(C)$, que responden a una posición perpendicular al frente; piezas, en general, que el escultor iba pegando, según le fuesen necesarias para modelar las diversas superficies, al retirarse del nucleo central inicial. Tablas de pino que en la talla de Mena y en su realización, llegarían hasta la letra (D), del dibujo, y que posteriomrente se vaciarían y ahuecarían, para dejar el manto «visto» interiormente y poder tallar las mangas de la túnica.

El núcleo central, señalado con la letra (A), fue tratado durante toda la factura de la talla y al terminarse esta, se ahuecó, hasta una altura, medida desde la base, de unos cuarenta centímetros, quedando macizo el núcleo central, interiormente, que se señala en el exterior desde donde se cruza la toca,

13. Sobre el ensamblaje de una escultura en madera del siglo XVII. No hemos localizado ninguna publicación; lo único que trata algo del tema es el capítulo de «La talla en madera» de Sánchez-Mesa Martín, D.: Técnica de la escultura policromada granadina, Granada, 1971, pp. 28-32. 
hasta el borde superior del manto en la cabeza. Este hueco evitaría el mayor peso y facilitaría la manipulación interna de la misma, para encolar y terminar los aderezos finales.

La figura 4, deriva de la apertura que se practicó, por una de las grietas dorsales a la talla, correspondiente a una de las tablas adosadas paralelas al frente, señaladas con la letra (B). Nos presenta la imagen vista en un Corte Dorsal, en el que se aprecia el hueco central vaciado, con la letra (G), y la prolongación del nucleo central hacia arriba; también las superficies correspondientes al manto señaladas con la letra (D), y la leve inclinación del núcleo de cedro, que deriva de la misma que tiene la Dolorosa; si la observamos frontalmente, esta inclinación es hacia la derecha, que en la figura 4, es hacia la izquierda, al aparecer en Vista Dorsal. Por último, esta figura también señala el tamaño de la ampliación que sufrió la escultura, recien terminada en el taller de Mena; figurando en el dibujo con la letra (F), que como citamos anteriormente, corresponde al gusto del cliente, y propietario de la Dolorosa, quien la encargó.

El Corte Lateral de la escultura (fig. 5), nos aporta: la posición de las tablas verticales adosadas, paralelas al frente (B); el nucleo central (A); el hueco central vaciado $(\mathrm{G})$; la pieza de la ampliación en la base (F); y la mascarilla del rostro de la talla $(\mathrm{E})$, que no fue realizado en el mismo núcleo de cedro, sino que fue adosada con posterioridad, realizada en cedro y pintada al oleo, a diferencia del resto de la imagen que es al temple.

La restauración de la talla, ha servido para consolidar definitivamente la escultura, y para introducirnos en la manera de ensamblar un imaginero del siglo XVII. Vertiente técnica de la escultura bastante interesante y poco tratada por los historiadores del arte, con la que, de nuevo, se pone de manifiesto la necesidad de valorar la parcela artesanal y profesional de la imaginería polícroma; cualidades sin las que no se podrían haber conseguido tales logros, de los que es máximo exponente en el género de la Historia de la Escultura en Madera esta obra de Pedro de Mena y Medrano.

Por último, destacar la labor del restaurador como elemento insustituible en la comprensión total de una obra de arte; tema que hoy día plantea amplias perspectivas. 


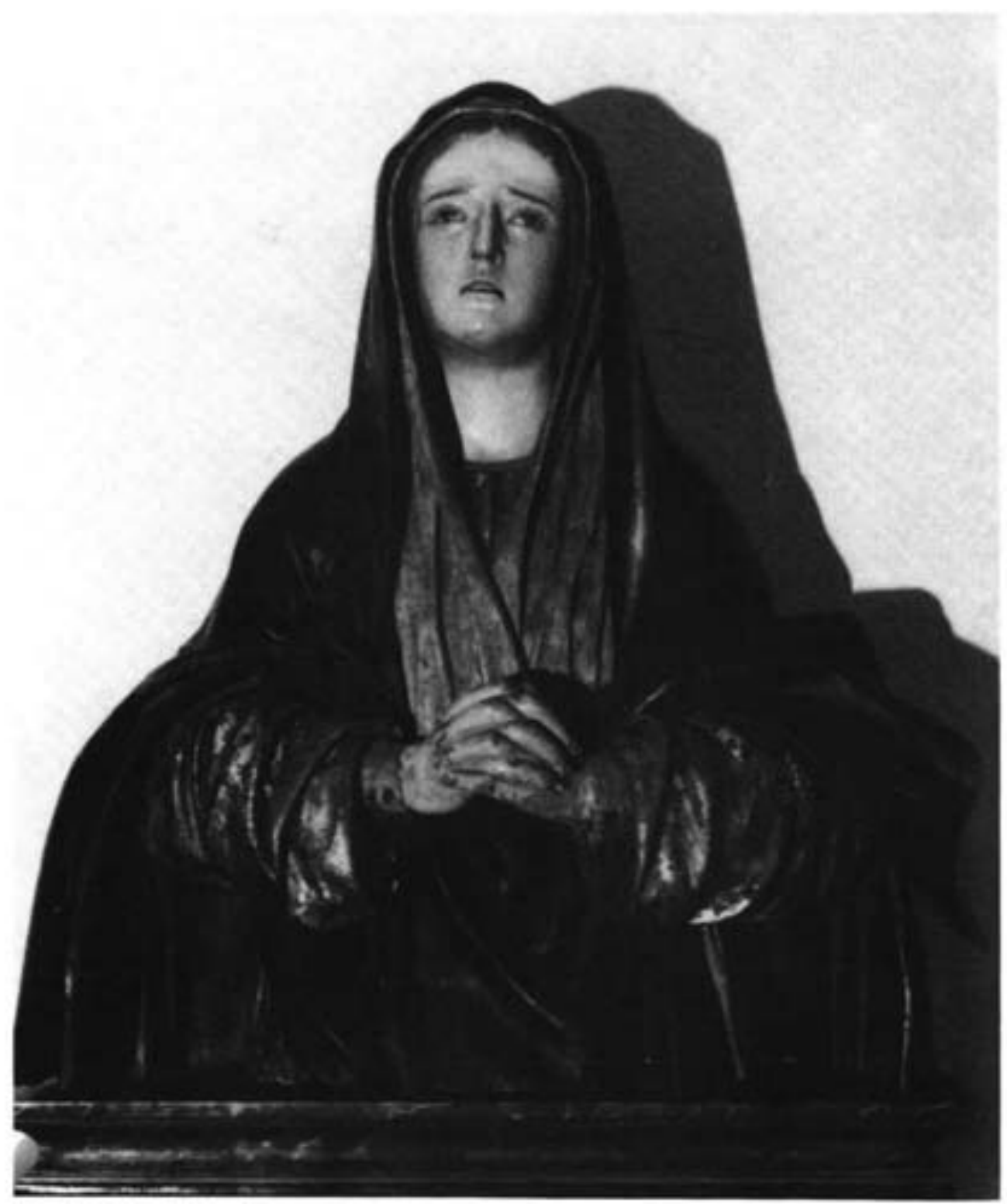

Figura I

Dolorosa. Pedro de Mena. Antes de la Restauración. 


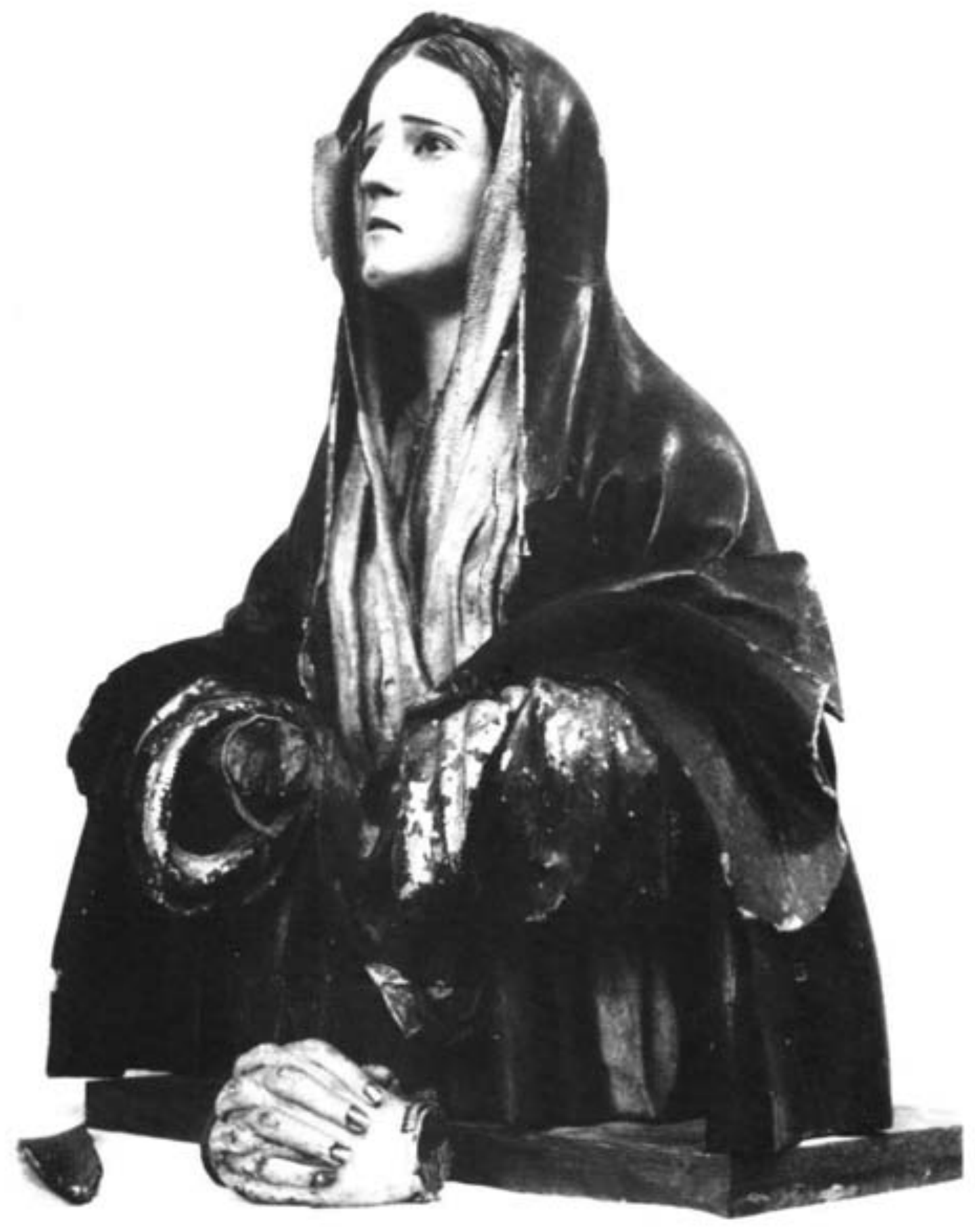

Figura 2

Dolorosa. Pedro de Mena. Antes de la Restauración. 


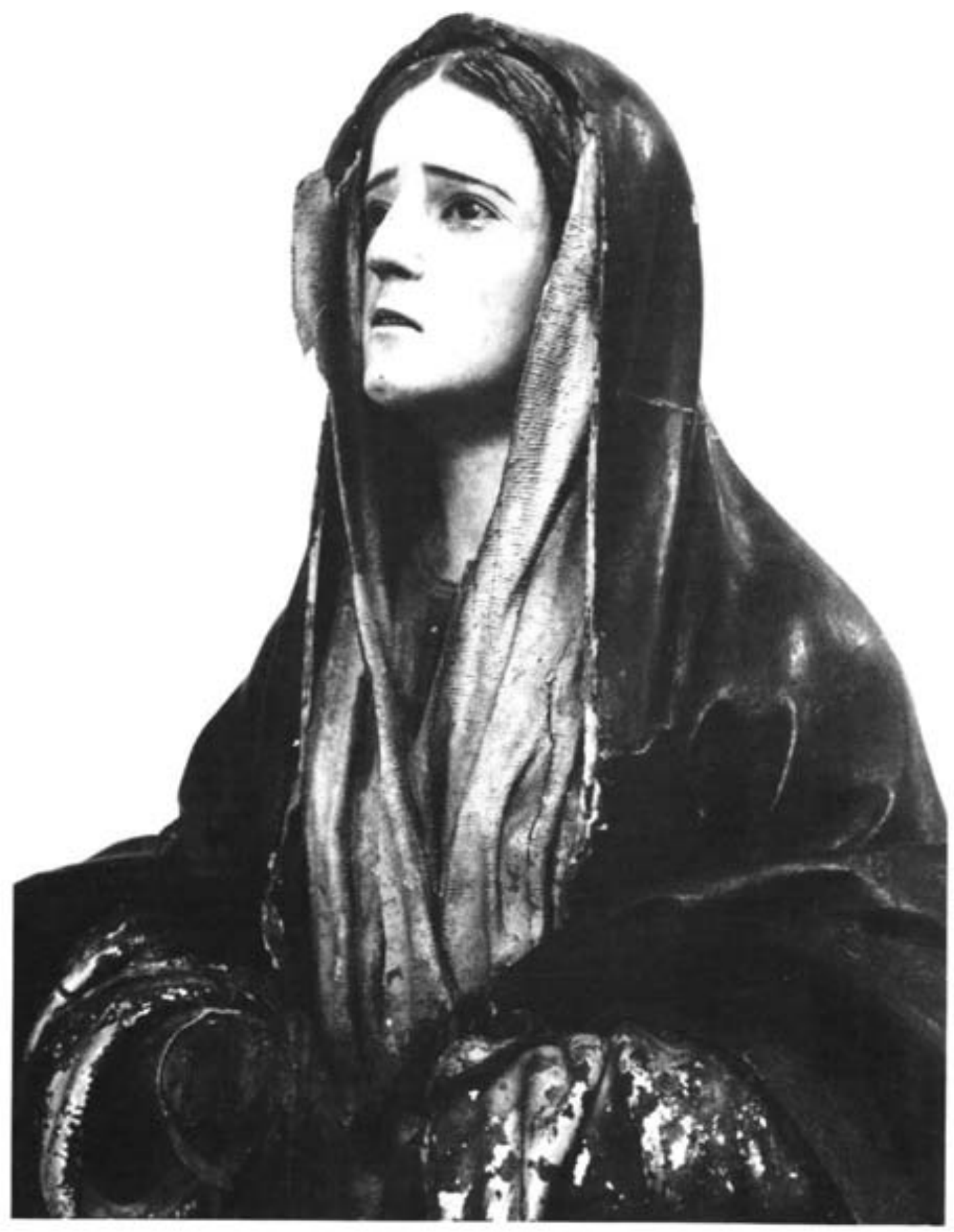

Dolorosa (Detalle). 


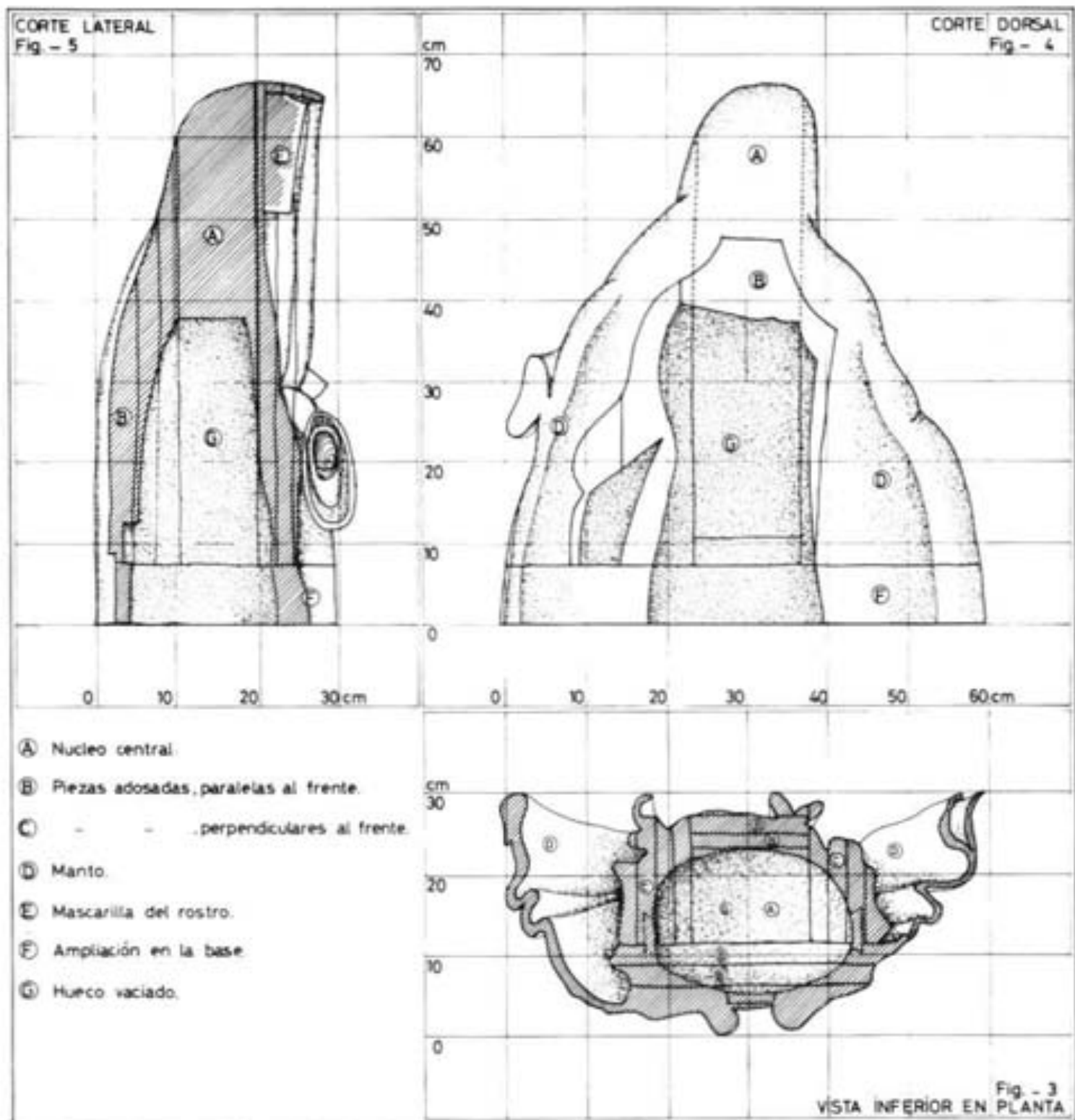

Figura 3. Vista Inferior en Planta.

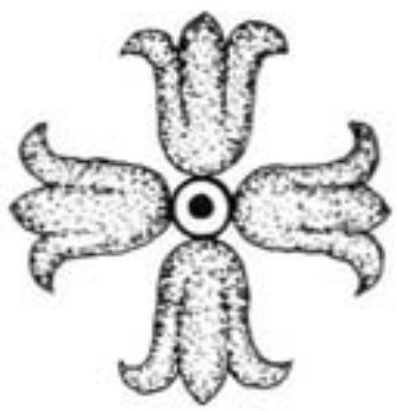

Figura 6

Motivo Decorativo de la Túnica. 


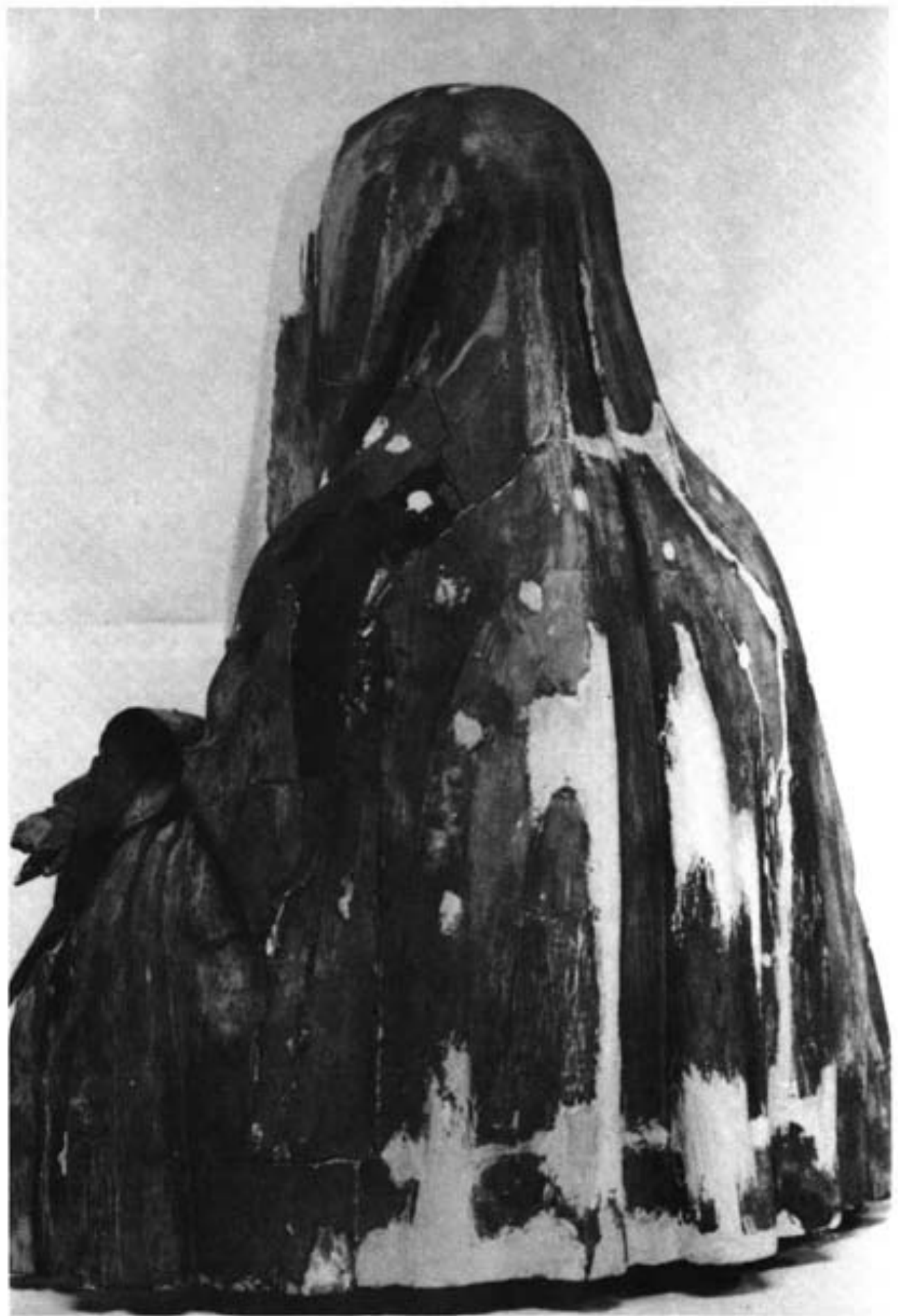

Figura 7

Dolorosa, en proceso de Restauración. 


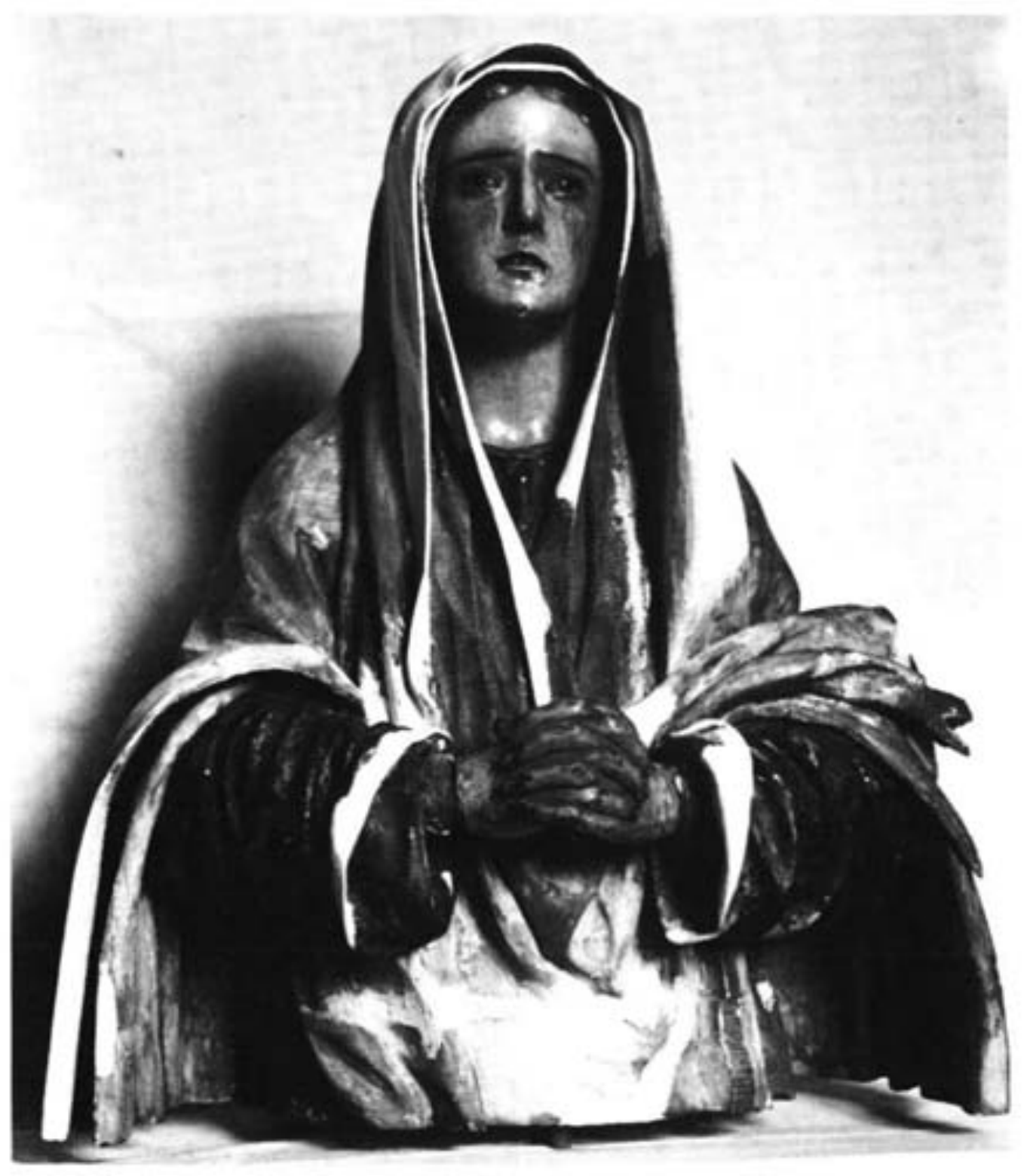

Figura 8

Dolorosa, en proceso de Restauración. 


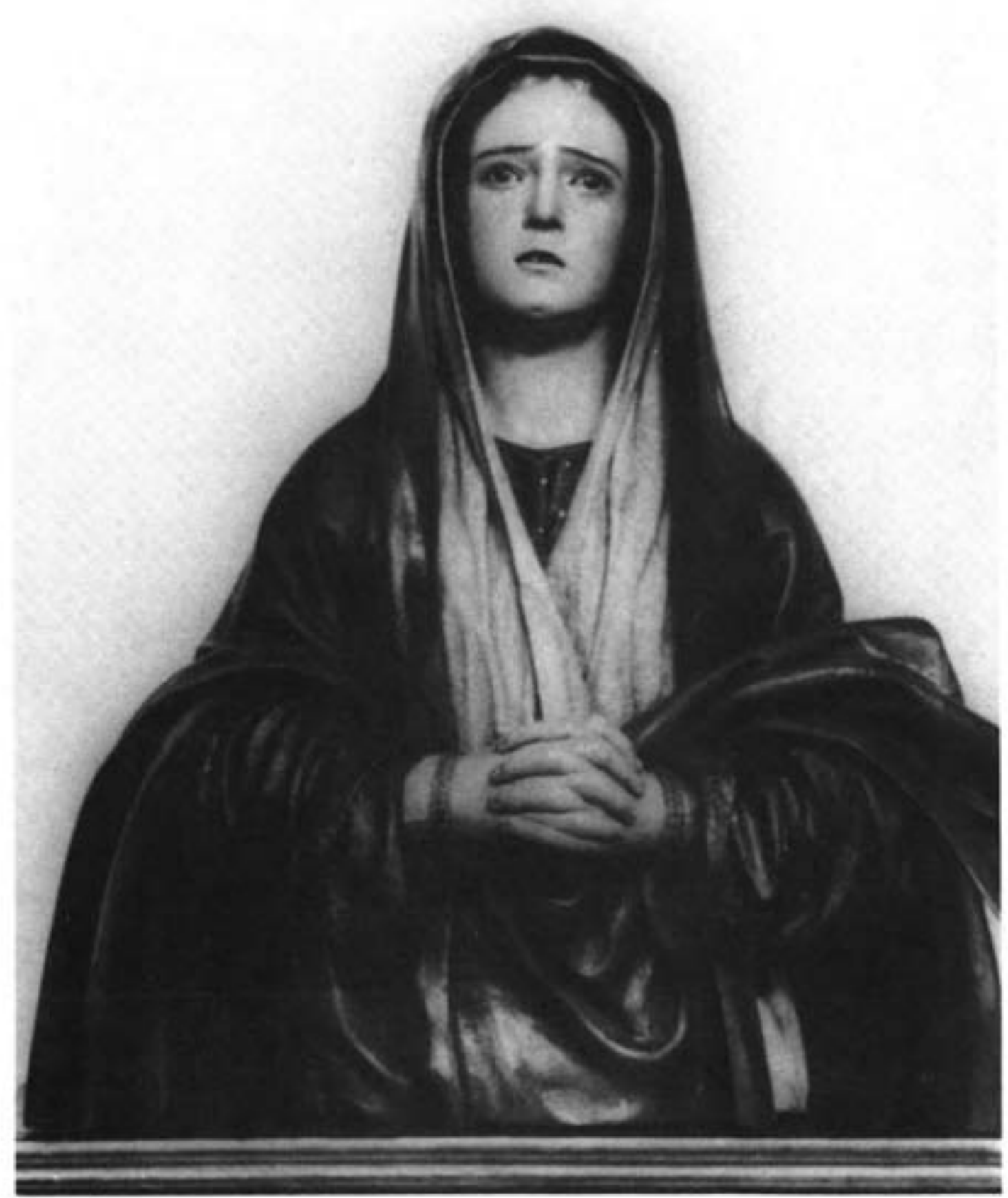

Figura 9

Dolorosa Restaurada. 